\title{
火山災害とその予測に果たす第四紀研究の役割
}

\author{
粐 倉 克 幹*
}

火山災害は, 火山噴火にともなう溶岩, 火砕物, 熱風 など火山噴火物の流出・降下，火山体の形成・崩壊など の火山からの外力と人間(生物)のかかわりとのあいだで 生じるものである.

したがって，火山噴火やこれに随伴もしくは関連した 現象が起こっても，それが人っ子ひとりいないところで 生命や財産の損傷とまったく無関係に起こったのであれ ば，それは災害とはいわない。

一方，わが国のように人口密度がたかく，かつ国土が 高度に利用されているところでは, 火山が噴火したりこ れに関連した現象が起これば，かならず何らかの災害が 発生し，噴火とこれに関連した現象は無関係ではありえ ないとみられている. その意味では，火山噴火やこれに 随伴もしくは関連した現象そのものを予測することは, 火山災害の軽減に貢献していることにつながっていると みることもできる. 図1 は, わが国の活火山の分布を 示したもので, 北方領土も含めて 83 カ所に及んでいる.

1990 年 11 月， 200 年間の眠りから覚めて噴火を再開 した雲仙普賢岳は, 1991 年 5 月 20 日以来ずっと溶岩を 出し続けており, 総噴出量は 1 億 $\mathrm{m}^{3}$ を超えたと見積ら れている。ドームの形成と火砕流の放出を繰り返してき ており，いまだその活動は衰える気配をみせていない. 噴火の開始時期や活動のタイプは予知されていたにもか かわらず，43 人もの命が火砕流によって奪われ，1 万 人以上の人びとが不便な避難生活を 1 年を超えて強い
られている.

溶岩ドームができたころの大方の予想は「1年もすれ ば治まるだろう」という楽観的なものであったが，溶岩 の噴出量は 1792 年のそれの 5 倍を超え, 止まるところ を知らない状態が続いている。このことを反映して火山 災害からの復興への目途がまったくたっていない．

このような状況を目の当たりにすると, 火山噴火やこ れに随伴もしくは関連した現象そのもの(一連の活動が いつ終息するかを含めて）を予知することの重要性と困 難性を認識させられる。 と同時に, 予知が現段階程度の 不十分さをともなっていても，人命が奪われず災害をも っと軽減できる知識や技術があるので，これらが結集さ れ知恵として適時に機能しなかったことを大变残念にお もう.

このシンポジウムでは, 富士山(上杉 陽)と雲仙(藤 井敏嗣）について，その噴火活動の動向とそのもたら 寸災害が話された，筆者は，これらの発表を災害予測の 側面からコメントしたが，その内容はここでは割愛す る.

火山災害を軽減することに大きく寄与あるいは貢献が 期待されているハザードマップは一般に図 2 の手順で 作成される。ここではその実例（図 3）と，これに関す る図 4〜図 7 (国土庁土地局，1987；1/25,000三宅島土 地保全図より）を参考のために揭載するにとどめる.

1993 年 10 月 19 日受付. 1993 年 10 月 30 日受理. 1992 年度第四紀学会大会シンポジウムにおいてコメント.

* 基礎地盤コンサルタンツ株式会社 T102 千代田区九段北 1-11-5. 

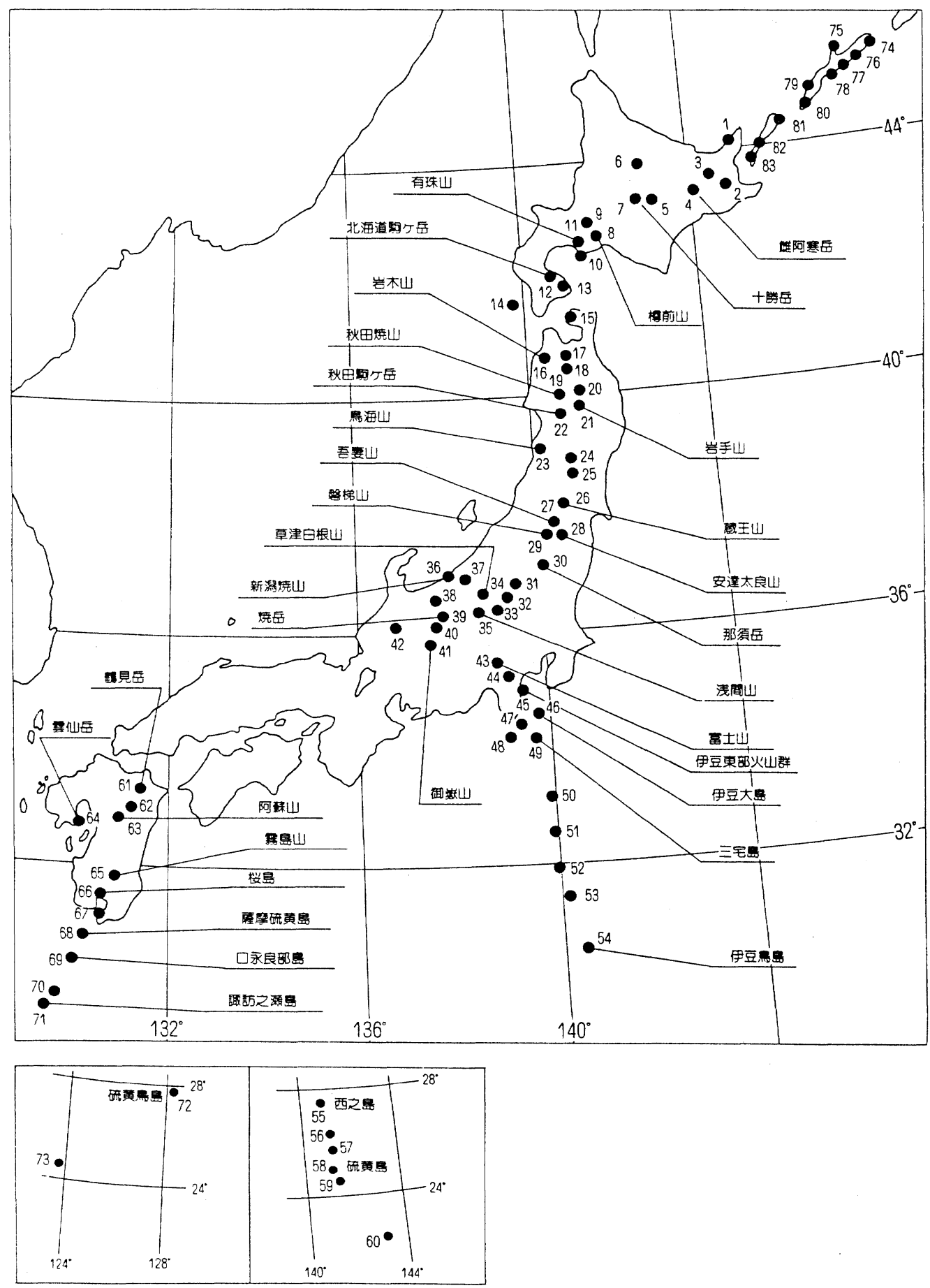

図 1 わが国の活火山分布（国土庁，1991） 


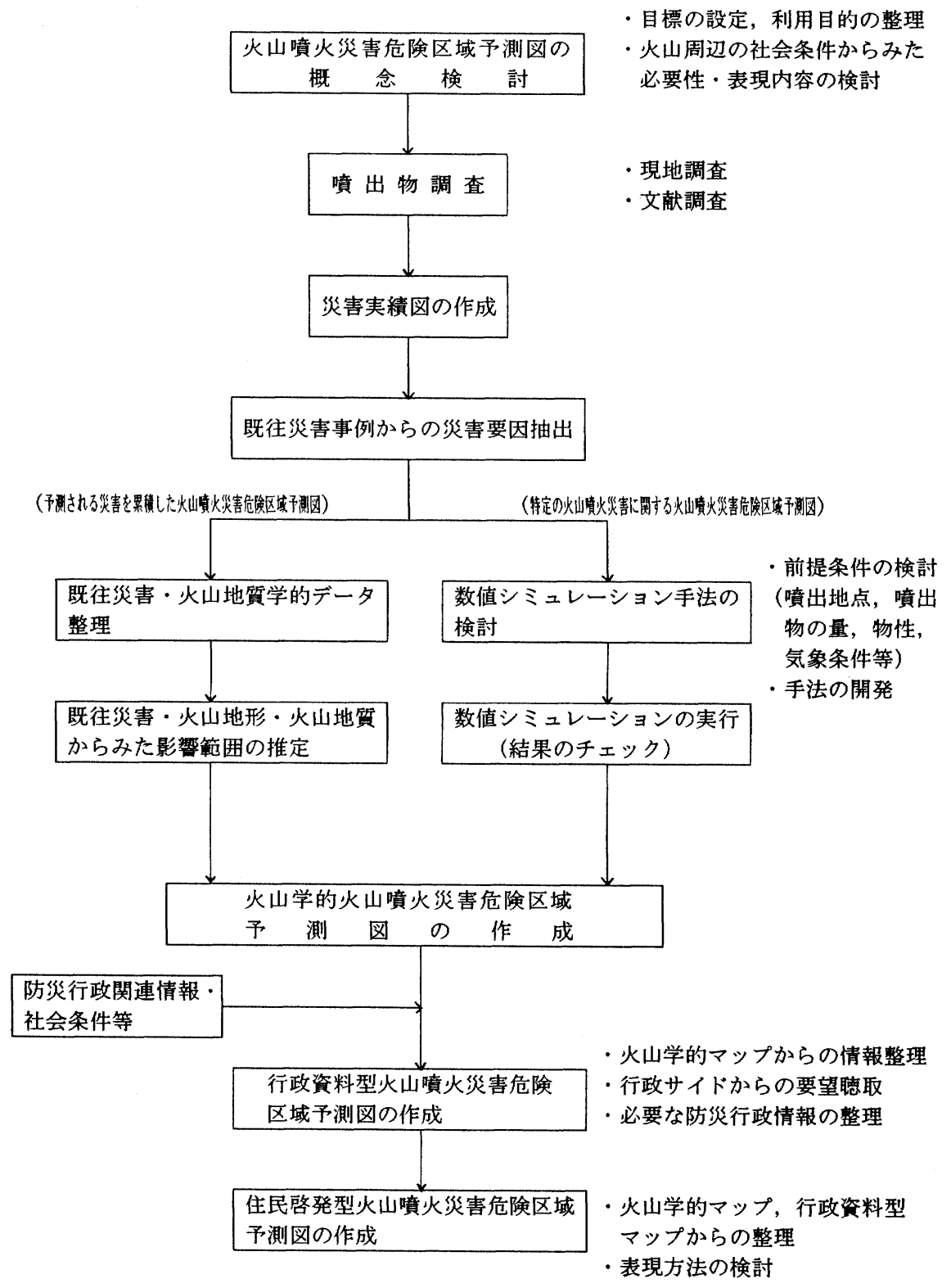

図 2 火山噴火災害危険区域予測図作成の流れ 


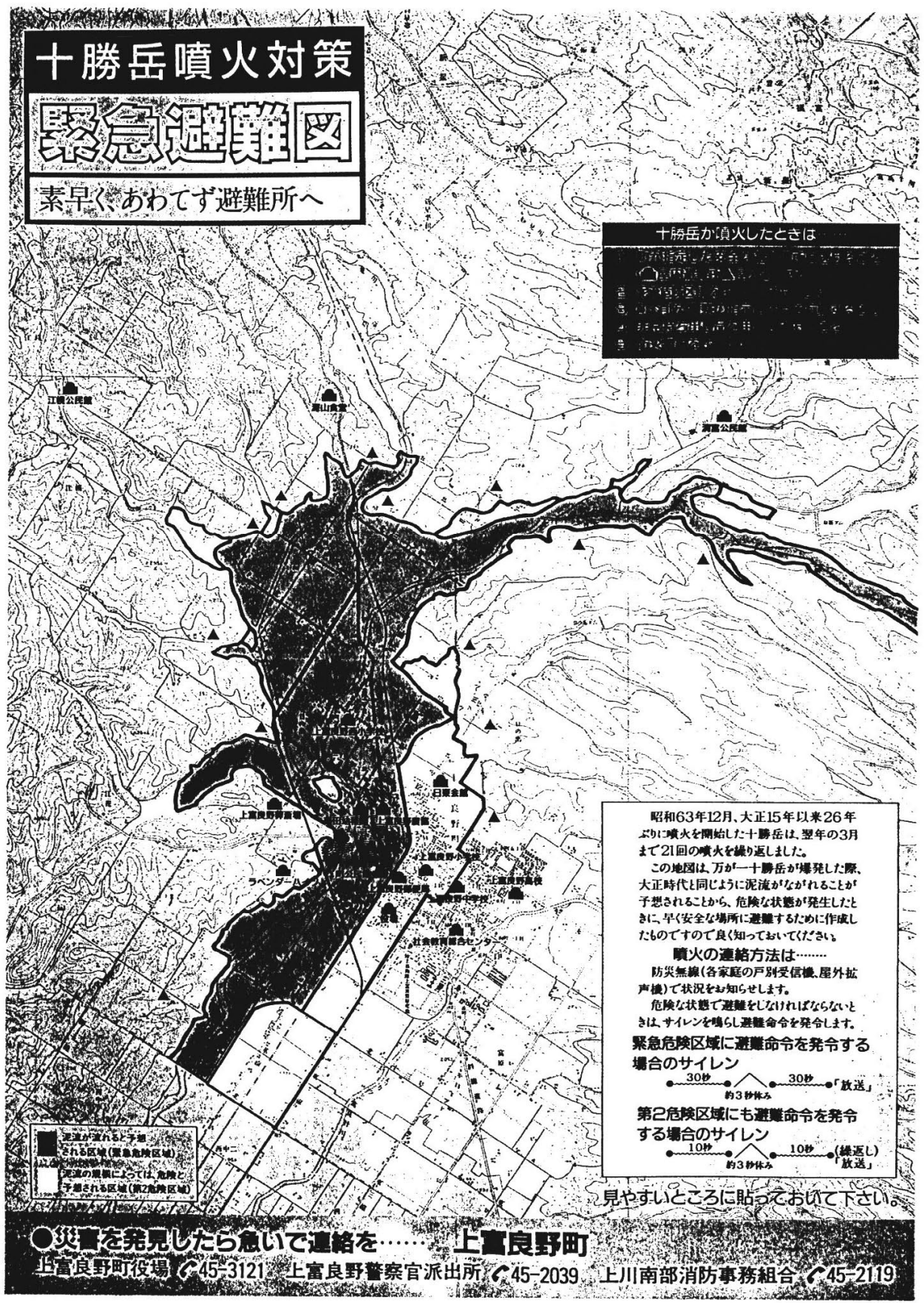

図 3 上富良野町の作成した住民㤵発型の火山噴火災害危険区域予測図 


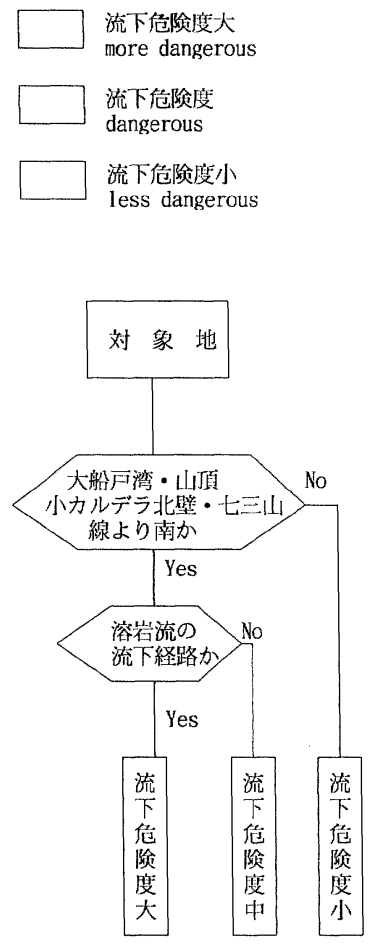

図 4 山頂噴火による溶岩流下の危険度
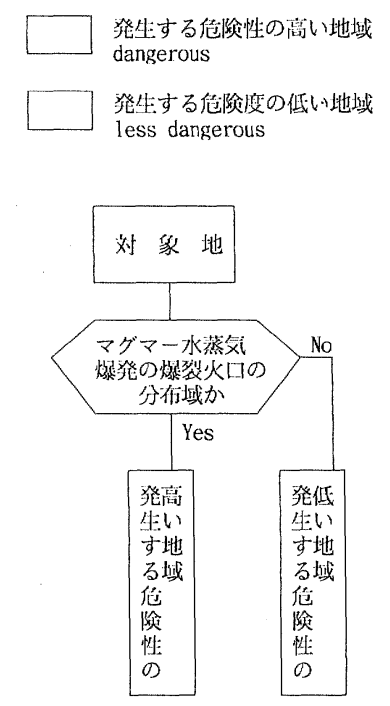

図 6 マグマ一水蒸気爆発の危険度

\begin{tabular}{|c|c|c|c|}
\hline & \multicolumn{2}{|c|}{ 溶 岩 流下 の 伦 烇 度 } \\
\hline & & 流下色隃度大 (1) & 流下伦㭘度小（2） \\
\hline \multirow{5}{*}{$\begin{array}{l}\text { 貲 } \\
\text { 火 } \\
\text { の } \\
\text { 绝 } \\
\text { 険 } \\
\text { 度 }\end{array}$} & 貲火危隃度大 (A) & & \\
\hline & 火口数 10 個以上 & $A-1$ & $A-2$ \\
\hline & 貲火危険度中（B） & & \\
\hline & 火口数 1 ～9個 & $B-1$ & $B-2$ \\
\hline & $\begin{array}{l}\text { 貨火绝狯度小 (B) } \\
\text { 火口数なし }\end{array}$ & $\mathrm{C}-1$ & $C-2$ \\
\hline
\end{tabular}

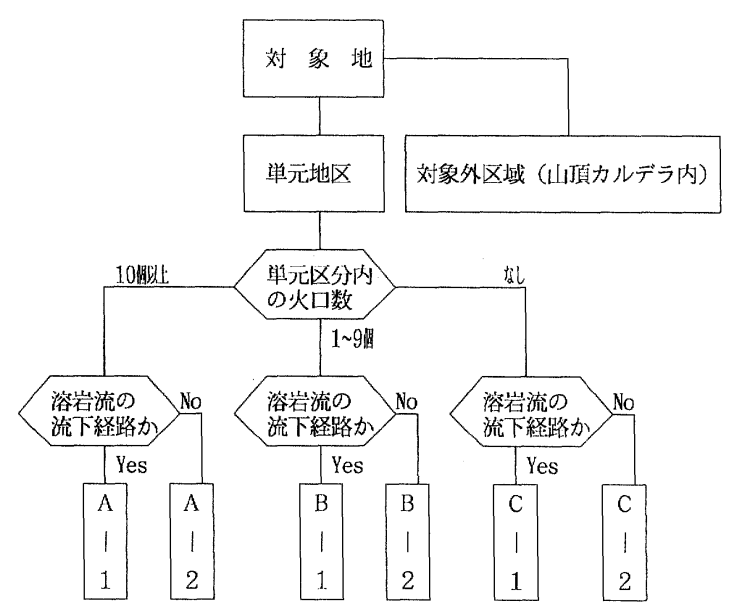

図 5 山腹噴火による溶岩流下の危険度 


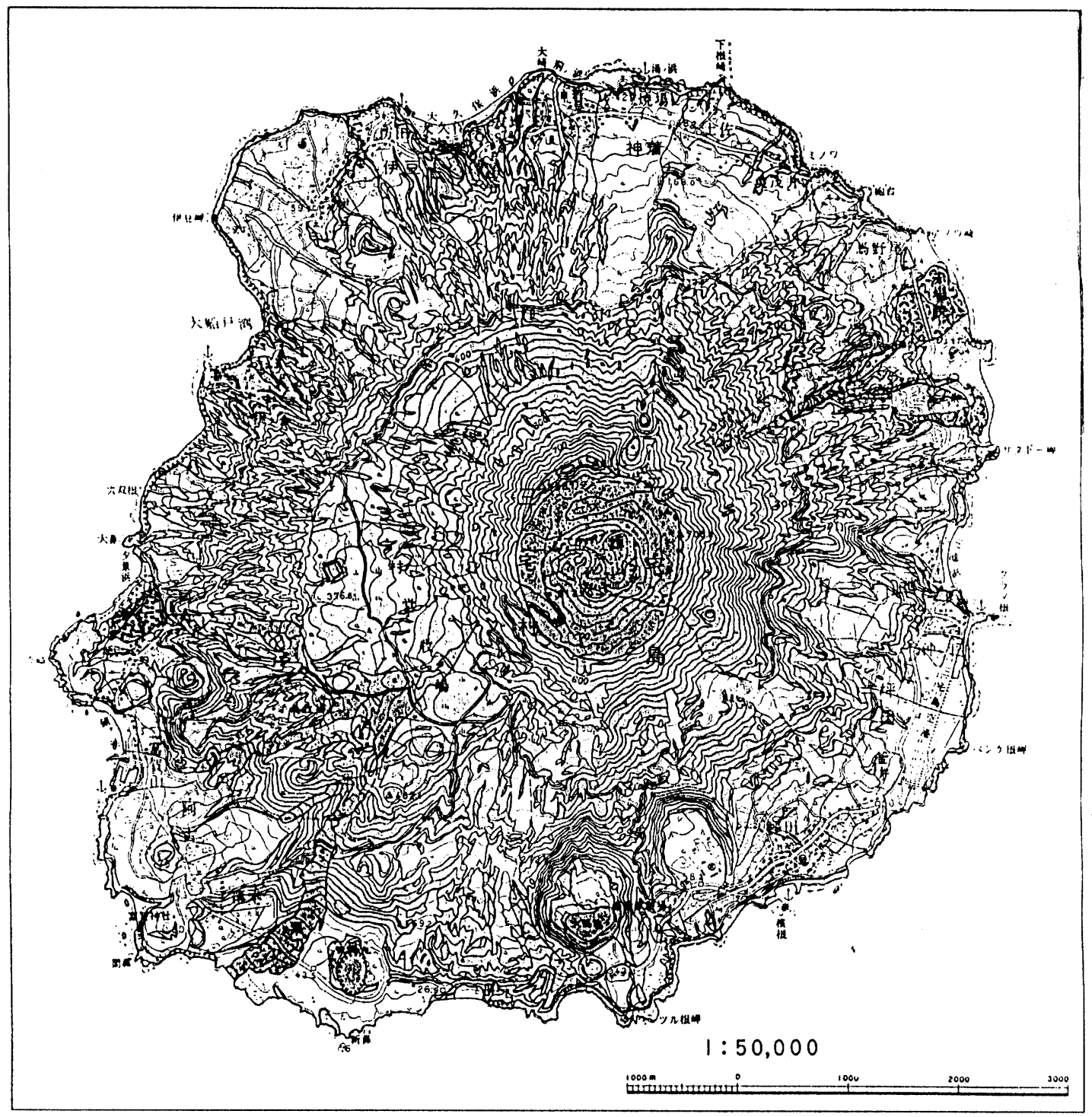

図 7 火山地域の土地利用適性評価図 
I - a 地区

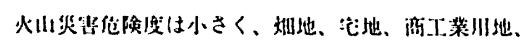
牧草地、朴地に利用することができる。

Capable area for field, settlement, commercial and industrial region, pasture and forest.(less dangerous)

I - b 地区

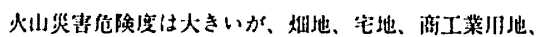
牧草地、怅地に利川することができる。

Capable area for field, settlement, commercial and industrial region, pasture and forest.(more dangerous)

II-a 地区

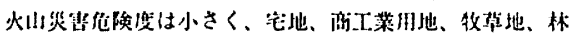
地に利衎ることができる。

Capable area for settlement, commercial and industrial region, pasture and forest.(less dangerous)

II-b 地区

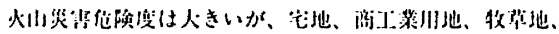
朴进に判川することができる。

Capable area for settlement, commercial and industrial region, pasture and forest.(more dangerous)
III-a 地区

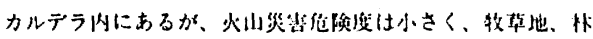
地に利川することができる。

Capable area for pasture and forest in caldera.

(less dangerous)

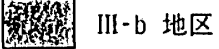

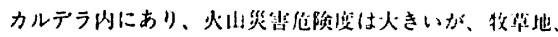
林地に利川することができる。

Capable area for pasture and forest in caldela. (more dangerous)

\section{N 地区.}

朴地に利川することができる。 Capable area for forest.

\section{V 地区}

土地利川か困難でちる。

Difficult area for land use.

Y. Momikura : Some Comments in Assessing the Volcanic Disasters. 